\title{
Twenty-Three Recent Arabic Films Impressions from two film festivals (Oslo and Tübingen, 2016)
}

\author{
STEPHAN GUTH (University of Oslo)
}

In this article, a preliminary attempt is made to describe my first impressions about a number of films that were shown at two Arabic film festivals I attended this year (2016), the first in April (Oslo/Norway) and the other in October (Tübingen/Germany).

In line with the focus of the In 2016 project to which this study is catering, ${ }^{1}$ most of the films that will be treated below are from Egypt and Tunisia (supplemented with a few productions from other Arab countries), and most of them have been released only recently, during the current year; some came out in 2014 or 2015, but they will nevertheless be included in my survey, given that they were screened in 2016, either abroad or in the respective countries themselves.

Most of the films are co-productions realised by Arab producers together with nonArab (European) companies. This, as well as the fact that they evidently also were made, though probably not exclusively, for a non-Arab public, will have to be given due attention at a later stage, when the In 2016 project will have completed the collection of material in the countries themselves and will have proceeded to the analysis and assessment of the respective data. At the present stage, the operations will remain on a more descriptive level.

In what follows I will treat the documentaries first, then the fiction films, with Magdy Saber's (semi)autobiographical La Vallée du Sel and Tamer el Said's largely autobiographical (but also fictionalised) In the last days of the city situated somewhere in between. Within the two main categories, I will proceed chronologically, starting with films that were first released before 2016 but are now shown again, then moving on to the "2016 proper" works. My approach will be little structured, impressionist-essayistic rather than analytically systematic. As a consequence, an idea of recurring themes and structures will emerge only in the course of reading, with each new film triggering new observations and associations. I will however highlight in bold from the beginning those elements that seem to have the potential of becoming relevant for the In 2016 project, either because they are dealt with in several of the films I watched, or because I feel I can 'link them up' to elements that I found to be prominent in novels that have been on the long- and shortlists of the International Prize of Arabic Fiction (IPAF), as analysed in another study. ${ }^{2}$

1 Cf. my own Introduction to this special dossier of JAIS.

2 Cf. GuTH $* 2017$, in preparation.

Journal of Arabic and Islamic Studies • 16 (2016): 298-326

(C) Stephan Guth, Dept. of Cultural Studies and Oriental Languages, University of Oslo (IKOS), Norway 


\section{Documentaries}

Among the documentaries presented at the Arabic Film Festival (AFF) Tübingen was a selection, made by a prize committee, of the best five shorts (18-25 mins.) that had emerged from two workshops organised in 2014 and 2015 by the German Goethe-Institut in cooperation with the Institut Français de Tunisie. The workshops were meant to encourage especially young filmmakers and were held under the motto Ensemble ("Together").

\section{\#1 Shüf/Chouf}

Shüf / Chouf ("Look!", 2014) by Imen Dellil portrays the everyday life of a poor blind couple in Testour (N Tunisia). The couple has two children: a little boy (2,5 years) and a daughter (still a baby in the cradle). The film not only presents the couple as being capable of surviving despite difficult living conditions, and of mastering the challenges of everyday life despite their handicap, but is also eager to show their modesty and contentment with the little they have, perhaps even a kind of happiness. The viewers learn from the protagonists themselves how they found each other and had a romantic affair, and that they still love each other. They are also shown laughing a lot, and as tender, patient parents of their children. - In this documentary we can already observe a number of features that we will meet quite often below when discussing other productions, fiction and non-fiction alike: the focus on everyday life, the description of dire living conditions / poverty, the affirmation of humanity (love, laughing, tenderness); the overall message of the film - which I think is exactly this affirmation of the possibility of a life in dignity against all odds - is profiled by way of an (implicit) contrast between the handicapped protagonists and what they actually manage to achieve in spite of an underprivileged position (cf. the title "Look!" given to a film about a blind couple). The impotence that a viewing public presumes in blind protagonists (cf. also the opening scene which shows nothing but a black screen, putting the audience in the position of the blind man who has to find his way with the help of his cane) makes them into 'heroes' with whom spectators who themselves feel powerless can easily identify.

\section{\#2 Condamné à l'espoir}

Condamné à l'espoir ("Doomed to hope", 2014), a short film by Yūsuf Bin 'Ammār (Youssef Ben Ammar), takes up another prominent topic of our times: the radicalisation and subsequent sudden 'disappearance' of young men (shabāb) who drop out and join the forces of the ISIL. Doomed to hope - a rather desperate hope - are the bereaved parents, a couple belonging to the less well-off in Tunisian society. In this film, like in many others (see below) as well as in much of contemporary Arabic print fiction, ${ }^{3}$ we can observe a forced effort to explore the past, with the aim of finding explanations for what has happened and caused the present tragedy. The fact that the son one day simply was gone, probably to join the jihadists in Syria, hits the parents like a bolt out of the blue and continues to paralyse them throughout the film, which makes them similar in their powerlessness to the blind couple of Shüf (cf. also the title "Doomed to..."). Like the latter, the

3 Ibid. 
parents here, too, are the focalisers whose perspective the viewer is made to share and with whom a broader viewing public will be able to identify - not only because of their feeling of impotence, but also because of their belonging to a large group of Tunisian society: those living on the verge of poverty (the father is a secondhand dealer, trading in all kinds of used commodities and rummage; when the film shows him in his shop there are never any clients; the mother is a housewife), struggling to survive in dignity. Now, both go back with their memories to the son's childhood, his school years, etc., trying to understand when and why the son mutated from a 'normally' religious-minded boy to a radical extremist and whether they could possibly have foreseen and prevented it. As in $S h \bar{u} f$, the author of this short film too is eager to portray the protagonists' daily routine, stressing the fact that everyday life must go on despite the fatal incision suffered and the loss of meaning. The epilogue provides the audience with a table stating how many young people per country have joined the ISIL jihadists so far, with "Tunisia: 3000 " topping the list. ${ }^{4}$ In one of the last scenes the film accompanies the couple on their trip to a gathering of other parents who too have lost their children to ISIL and do not know anything about their whereabouts and further destiny. The women hold up pictures of their sons, and on a banner we read: "Give us our children back!"

\section{\#3 Les commerçantes}

With Les commerçantes (“The tradeswomen”, 2015) by Noussaiba Msallem we return to productions that, like $S h \bar{u} f$, end on a more positive note. The film portrays a group of women from the Tunisian South who regularly cross the border to buy and sell commodities, mostly clothes, on public markets in neighbouring Algeria. It shares with the two films discussed so far the authors' eagerness to show ordinary people in everyday life contexts, highlighting their efforts/struggle to cope with the challenges of the present (how to survive and live a life in dignity). As is clear already from the documentary's title, the focus here is on economy (a key issue in post-revolutionary Arab countries) and on women running their own business. The latter can probably be interpreted as a focus on one of the many facets of emancipation from the traditional authoritarian-patriarchal system as well as, perhaps, as in line with the previous two films' choice of underprivileged, 'handicapped' protagonists (women as the allegedly 'weaker sex'). At the same time, what also seems to have made this specific group of women into attractive subjects for a documentary filmmaker was probably their inventiveness and creativity (a key quality in the daily struggle for survival) combined with courage and self-confidence. It is with these qualities that the protagonists manage to have a rather positive outlook on life, reflected not only in their colourful dresses, but also in the merry atmosphere on the little van that takes them to Algeria in the middle of the night, hours before sunrise (the film's opening scene); it does not take long until the viewer witnesses them singing, clapping, engaging in lively conversation, laughing (again expressions of humanity).

The fact that the author turned her interest to the Tunisian South has certainly to do with the inner-Tunisian discussion about the discrimination of this region as compared to

4 The distribution shown in this list (without indicating a source) conforms roughly to the one to be found in articles like KIRK 2016. Given that statistics, for obvious reasons, vary considerably, the data provided in the film should not be taken as incontestable objective facts but rather as an expression of the author's wish to underline the relevance of the addressed phenomenon for Tunisian society. 
the capital, a discussion that, as we shall see below, is going on likewise in other countries (capital vs. provinces, centre vs. periphery) $)^{5}$ and can, or should, in its turn be seen as expression of an anti-authoritarian drive: the underprivileged, discriminated, marginalised raising their voice against the dominant ruler, master, exploiter, etc.

\section{\#4 Travesties}

Enjoying life and feeling like a human being is also the topic of Safoin Ben Abdelali's Travesties (2015). The film accompanies three young cross-dressers who, after having bought the outfits they need to spend a formidable night in a disco, take the train from Gabès to Sousse, where they start, in a hotel (?) room, preparations for the night. This includes discussing their shopping, (whole body) shaving/depilation, hair-dressing / putting on their wigs and make-up, testing the newly acquired high-heels, and excitedly anticipating how good it will feel to go out in this dress and dance. Larger parts of the 21-minute film are then dedicated to the evening/night at the disco. While the sections before and after consist to a large extent of dialogues, in the disco scenes music and close-ups of the almost ecstatically dancing bodies take over completely, underlining emotional intensity, the physical experience, and the jolly, frolic atmosphere (pleasure) all this gives room to.

Like the films discussed above, this production too sheds light on a marginalised social group. The fact that the three men have to travel from one city in Tunisia to another may serve the function of underlining that transvestites cannot live their identity openly at home; in order to be truly themselves they have to translocate to a place where anonymity allows for a larger degree of freedom. The film can serve as an example of productions that describe the emancipation from taboos and 'being yourself' as a great physical experience, whence the strong focus on the bodily (it is probably therefore that the camera often does not show the protagonists' faces but only their bodies, or some details of these). Not untypical is also the fact that the film perhaps has an autobiographical component: in a scene on the train to Sousse we hear one protagonist (= the author/director?) say that it was here that "I started to write my 'autobiography", 6

5 Cf. a similar predilection recognizable in IPAF-listed novels like 'Azāzīl (winner 2008) by Yūsuf ZAYDĀN (moving between the Egyptian South, Alexandria, Jerusalem and a remote monastery in northern Syria), Isțāsiyyah (longlisted 2011) by Khayrī SHALABĪ (events unfolding in the Egyptian Delta), Tawq al-h̆amām (winner 2011) by Rajà' 'Ālam (Mecca), al-Iskandariyyah fi ghaymah (longlisted 2014) by Ibrāhīm 'ABD AL-MAGīD (Alexandria), Ahl al-nakhīl (longlisted 2016) by Janān Jāsim ḤALĀWĪ (Iraqi marshlands), etc. - The idea of promoting the cultural production of the peripheries and support the (inner-Egyptian, for that matter) 'adab al-'aqālìm was also discussed on several occasions at the Cairo bookfair in Jan./Feb. 2016. For some time, it received support from the then director of the Hay'at qușūr al-thaqāfah, Prof. Muhammad Badrān (dismissed from office shortly after that). - The tension between capital and countryside is as old as the beginnings of modernisation and has, as an 'eternal' topic, of course also found its way into modern Arabic literature all from the mid- $19^{\text {th }}$ century onwards, as elaborated on by SELIM 2004 and already dealt with in detail by many others; cf., e.g., my own monography on the Turkish and Arabic novel, GUTH 2003, esp. § 100e, with further references.

6 It may, however, also simply be a statement by the speaker meaning "it was here that I started to be myself". 


\section{\#5 Un cercle autour d'une danse}

Self-realisation through dancing is also the topic of Un cercle autour d'une danse ("A circle round a dance", 2015) by Mouna Louhichi. The protagonists are even younger here than in Travesties: a group of teen-age (shabāb) hip-hop enthusiasts. Like in Travesties, dancing means "life" for them. In addition, the film problematises prevailing gender inequality even in such free-spirited 'dropout' circles (highlighting a certain inconsistency in their thinking and perhaps also the limitedness or incompleteness of the revolution?): although a male group of quasi-professional dancers show some openness for talented girls who would like to join them, and therefore let them perform in front of them, in the end the girls are not accepted into the group. The title of the film expresses both the interest the boys show in the girls dancing in their midst and the 'encircling' of the girls: it is as if they were imprisoned, despite their own emancipation and despite also the boys' 'progressiveness'. - The wish to feel/be yourself and to come close to such an experience via dancing is, by the way, not peculiar to 'western-looking' girls: the author also shows a girl wearing a hijab dancing in front of the male hip-hoppers (who, in their turn, obviously are openminded enough to at least give her a chance to prove her talent to them; later on, however, she too is not accepted into the male group...).

\section{\#6 Tahar Cheriaa: Taht zilāl al-bāwbāb / A l'ombre du baobab}

Not among the short documentaries that emerged from the above-mentioned workshops, but an independent (and also much longer: 70-minute) production is Muhammad Shallūf (Mohamed Challouf)'s documentary about the founder of the Carthage Film Festival (JCC, Journées Cinématographiques de Carthage), al-Ṭāhar (al-)Sharīa: Tahar Cheriaa: Taht zilāl al-bāwbāb / A l'ombre du baobab ("In the baobab's shadow", 2015). It is produced on the occasion of the celebration, in 2016, of the fiftieth ${ }^{\mathrm{h}}$ anniversary of JCC and as such certainly expresses some pride of the achievements of the past (past as treasure box). With this, the film is without doubt an expression of the wish to preserve the country's cultural heritage and make it bear fruits in the present or future. As underlined by one interviewee, it is important to know history "because history gives a sense of continuity" - a statement that comes towards the end of the documentary and therefore can be seen as a kind of conclusion. As the film highlights Cheriaa's capacity to attract many filmmakers from the Arab World, especially Egypt, and from Africa, his prominent role in the propagation of pan-Africanism and the cultural emancipation of "the South"-for many, he was a "father" and "shepherd"-, it implicitly also celebrates Tunisia's important contribution to the Third World movement (national pride); Egyptian and Tunisian viewers will perhaps also frame it as a statement related to the notorious Egyptian-Tunisian competition about cultural leadership in the Arab World. Seen from a present that is searching for a new cultural orientation, Cheriaa, whom the film praises as the big inspirer, can probably also be seen as a model of Tunisian inventiveness and creativity that once helped the country to recover from humiliation and regain national pride and dignity. With the celebration of the JCC founder comes also an affirmation of other ideas and values he represented, like anti-colonialism, independence, cultural self-determination, authenticity, the necessity of freedom of expression (motto: "Free the screens!"). The film concludes with what the viewers have to take as Tahar Cheriaa's 'message to the world': what mattered for him and his colleagues, and what made his generation successful, was (a) their 
strong belief that "only culture can be the foundation of progress", (b) their belief in the possibility to realise their project(s), and (3) their commitment to the cause of the nation.

\section{\#7 Yallah! Underground}

Farid Eslam's Yallah! Underground (2015) is an 85-minute documentary about political underground music in the Arab World (Egypt, Jordan, Palestine, Lebanon). With its discussion of the freedom of expression vs. taboos and its stressing of the importance of cultural production, it parallels some of the major topics of the homage to Tahar Cheriaa just discussed in the previous paragraph (\#6). The importance of dancing and music was stressed already in (\#4) Travesties and (\#5) Un cercle autour d'une danse; in Yallah! Underground, however, they function less as a means to help the body 'be itself' than as a politically subversive tool. Moreover, the film displays a feature that we will meet again on several occasions in the following: the eagerness, on the side of the author, to produce an assessment of the 'Arab Spring' by covering three periods: the time before the uprisings, the euphoria of the 'revolutionary' moment itself, and its aftermath.

\section{\#8 Egypt's Modern Pharaohs}

A focus on the political and on history is also seen in Jīhān al-Ṭāhirī (Jihan El-Tahri)'s documentary trilogy entitled Egypt's Modern Pharaohs (2015/2016; 3 x 58 minutes: I. Nasser, II. Sadat, III. Mubarak). The production is probably not particularly relevant as an In 2016 text since it seems to be made to serve the didactic purpose of a three-part series on pre-'Arab Spring' history that is to be shown outside Egypt. Nevertheless, we can register it as a film that shares with other documentaries, and also much fiction, the wish to understand and/or explain the present or, in this case, the recent past of the uprisings via an assessment of the deeper past. The story is told in a neutral tone, reminding of the 'dry' factualness of history textbooks, with probably no controversial statements, not even by the contemporary witnesses (interviews with whom enliven the narrative). Yet, the film is not completely uninteresting for the In 2016 project: first, because it documents a wish, on the side of an Arab author, to provide an English-speaking public with an illustrated explanation of the Taḥrīr events, and, second, because the assessment concludes - as the series title shows - with the idea of continuity, uninterrupted by the ideological, political and economic reorientations that each new president brought about, of a god-king-like, 'Pharaonic' ruling style (authoritarianism).

\section{\#9 'Abadan lam nakun 'ațälan}

While the social conditions/poverty of the masses appear only sporadically in Egypt's Modern Pharaohs, they are the main topic of 'Abadan lam nakun 'atfälan ("We have never been kids", 2016) by Maḥmūd Sulaymān (Mahmood Soliman). In this long (99-minute!) documentary, the author portrays an Egyptian family living on the breadline in one of the 'ash wa $\overline{\boldsymbol{a}}$ 'iyy $\overline{\boldsymbol{a}} \boldsymbol{t}$, the mushrooming 'informal' quarters of the capital. The conditions shown are even worse than those we met in $\operatorname{Sh} \bar{f}$ (\#1): while the Tunisian blind couple's home was relatively spacious and had a direct connection to the public water supply (own tap), the inhabitants of the Cairene slum live in rather cramped confines and have to get their water from outside, hygiene becoming problematic/precarious. The mother, Nādiyah, is separated 
from her husband whom she had married at an early age (arranged marriages) but then left because he had turned out to be too brutal (domestic violence) and did not provide for her and the children (idle man vs. hard-working woman). She tries to make a living from grinding knives and scissors, carrying the heavy equipment (grindstone etc.) along on her back. (Later on we learn that she had to give up this job because of health problems.) Although Nādiyah struggles hard to uphold a certain level of dignity and is also eager to send her four children to school (importance of education), her income alone is too meagre to survive and meet the challenges of everyday life (which the film is eager to document in some detail ${ }^{7}$ ); so all the children leave school after only a few years. The boys start to have some jobs at an early age (child labour), and although Nādiyah, remembering her own destiny, does not want to force her eldest daughter into a marriage, the latter marries nevertheless, fifteen years old.

The film is however not only a synchronic snapshot but has also a diachronic dimension: like Yallah! Underground (\#7) it is eager to follow the protagonists from the period before the Tahrīr uprisings up to the present. With this, it aims at a critical assessment of the 'Arab Spring' and the subsequent developments. It is based on an earlier documentary M. Sulaymān had shot in 2003 about Nādiyah's family (entitled "Living among us"), then resumes in 2011, to continue until the present. As the program leaflet aptly describes it, the film "shows the decaying social, political and economic situation during the last decade of the Mubarak regime," then "highlights the moment of dazzling hope" during the January 2011 uprisings (in which the family participates), to continue with a documentation of "the chaos and disillusionment that have had a firm lock on the country ever since" (AFF: 5, my translation). The assessment is achieved by a comparison, made also in many other productions (see below), of the 'Before' with the 'After', from which the viewer retains the impression of an alarming worsening of the living conditions, despite (or perhaps as a sad consequence of) the "Revolution". It also shows, first, a hope in the possibility of political participation (Nādiyah is on Tahrīr Square in January 2011 and a voter also in the elections that are held in the following years), but then, since Sīsì's takeover, she does not care about elections any more: "I don't know the candidates any longer," and "we are back to the situation as it was under Mubārak: we are no longer part of the game."

As is clear from the title ("We have never been kids"), the author's major concern are the children who are deprived of their childhood. This is why Sulaymān dedicates large parts of his film to the documentation of the life trajectories of the three eldest who are forced to contribute to the family's living from an early age. While the daughter obviously feels forced to relieve the family of the burden she represents as an additional eater and therefore agrees to marry at an early age (see above), the author shows the two sons working from the age of 10-11 in several places every day from early morning to late evening (Khalīl as a drummer in a wedding band, a casual worker at building places, a parking attendant (sāyis), etc.; Nūr as a cook's assistant in a kosharī restaurant and as a tuk-tuk driver), hardly enjoying what they do, but mostly concerned about assembling the money

7 The narrative starts on an average morning, then continues for some time through an average day: waking up, bringing the children to school, grinding knives in public places, later having sandwiches together on the street, on a piece of cartridge, drinking from a public water jug (qullah) or a tap in a sabill, etc.

$J A I S \cdot 16(2016): 298-326$ 
the family needs to survive. The hard work and responsibility weighing on them makes them prone to drugs, incl. heavy smoking, or falling prey to the temptation to earn a few piasters/pounds in an "easier" way: by prostitution. From the interviews with the younger son, Nūr, it becomes clear that he serves a blind man, himself a beggar, as a mate, and later remains/becomes homosexual himself-which makes life even more difficult for him, given the persistence of society's discrimination of homosexuality as "abnormal" $(s h \bar{a} d h d h)$ sexual orientation. The psychological pressure upon him becomes all the more difficult to bear as his mother and elder brother condemn his leanings, Khalīl being beside himself with rage because he thinks Nūr is dragging his and the family's honour in the mud; at the end of the film, the boy has disappeared, with nobody knowing anything about his whereabouts. ${ }^{8}$

The persistence of traditional attitudes in these destitute milieus is also highlighted in a scene in which the daughter (11 years), asked if she prays regularly like her brothers, replies, "No, I don't, because, as mum told me, my prayer wouldn't be heard anyway because I'm using nail polish." And when she marries at the age of 15, we learn that her mother was not convinced that this was right, less however on account of her own history, but more so because the signs of the future couple did not seem to match (horoscope)!

The film is highly significant in the context of our In 2016 project on account of yet three other features:

Parallel to the narrative of a deterioration of the living conditions runs a thread showing the dying of human emotions: not only is Khalīl ready to kill his brother on account of the alleged maculation of the family honour, but also Nādiyah, on seeing her ex-husband lying clinically dead in a hospital after an accident, states that she has no feelings at all left for this man.

The film closes on yet another alarming note: While the screen is black, we hear Khalīl telling the author on the phone (in a recorded call) that he, too, is leaving now- to join the ISIL forces-because he has come to a point where he either has to die himself or kill others (cf. \#2, Condamné à l'espoir, above).

Like many other productions, Sulaymān's film too often contrasts (by way of uncommented juxtaposition) reality and official discourse. In the very opening scene, for instance, the viewer not only gets an impression of the poverty at the family's home but at the same time we are made to hear a voice from the radio talking about the government's successful promotion of job opportunities, good-quality education, etc. In a similar vein, the miserable conditions prevailing at the elementary school that Nādiyah makes her children attend are accompanied by patriotic slogans shouted and the national anthem sung mechanically by the pupils standing at attention during the morning muster. Also, when Nādiyah, in 2012, casts her vote in the elections, the camera swings to zoom on the name of the primary school that serves as a polling station: "Madrasat 'Abd al-Nāṣir al-

8 In the public discussion following the presentation of the film, with the author being present himself (October 9, 2016, at d.a.i., Tübingen), a viewer (obviously with Egyptian background herself) raised the question whether M. SULAYMĀN's insisting on getting answers from the boy about his sexual orientation may possibly have contributed to Nür's decision to drop out and leave, knowing that the film would be shown to a larger public. The author replied that the family had been asked their consent beforehand and that sensitive sequences had been cut out for the screening in Egypt (at the Luxor festival). 
Ibtidā'iyyah", in this way evoking a feeling of contrast between the present condition and all the sublime values the name of the legendary president stood for.

\section{Between autobiography and fiction}

\section{\#10 al-Ṣalāt wa'l-ma'rakah / La vallée du sel}

The last documentary I will treat here shares with the next one a certain 'in-betweenness': in both of them, the author himself (\#10) or his representative (\#11) form part of the reality that he sets off to document (outsider $=$ insider). However, while all characters in 'Ākhir 'ayyām al-madīnah (\#11) bear fictitious names (despite the movie's evidently autodocumentory function) and are played by professional actors, the author of al-Salät wa'lma'rakah / La vallée du sel ("Prayer and battle / The Valley of Salt", 2016), Christophe Majdī Șābir (Magdy Saber), and his parents are 'real life' persons. While 'Ākhir 'ayyām almadīnah has its main focus on the young filmmaker (Tāmir al-Sa '̄̄id alias "Khālid") himself, Christophe M. Șābir reserves for himself the role of an observer and makes his parents the main protagonists. He is drawn into the events because he happens to be the son of an Egyptian-Swiss Christian couple. The parents are exposed to death threats reaching them via cell phone, probably from somewhere in the neighbourhood (the treacherous neighbour). The period covered spans over two-three weeks, from Christophe's arrival in Cairo (he studies abroad) in December 2012 until his departure in January 2013. The Egyptian father characterises it as a period of post-revolutionary anarchy in which there is no security any longer and some youth groups (shabāb) with Islamist leanings feel encouraged by the religiously-oriented Mursī government to take advantage of the lack of police control and exercise terror on non-Muslim minorities, also with the aim of pressing money out of them (blackmail). The film shows how the death threats affect the couple's everyday life (esp. their running a Christian conference centre in the Wādī Națūn, on the desert road between Cairo and Alexandria) and plans for the future as well as, of course, the relation to their son: In one of the first scenes the viewers witness the mother reminding her husband that they should get a power of attorney for Christophe, to provide him with the documents he would need in case they are killed and he would have to sort out the estate.

The main 'events' after Christophe's arrival and the scene just mentioned are (a) the family's trip from Cairo to the Wādī Natrūn where an international conference with c. 400 participants is held over Christmas, in spite of the dangerous situation, ${ }^{9}$ and then, back in Cairo after the event that the mother had feared might be their last; (b) the family's waiting for, and, when it eventually comes after two long days, the father's courageous answering the next call of the anonymous blackmailer (blocked caller ID). The latter legitimises the group's 'death sentence' on the couple saying that they have proof that the father has

9 The centre is called Agape, i.e. with the Greek (New Testament) term for "love: the highest form of love, charity; the love of God for man and of man for God" (LIDDELL/SCOTT, Greek-English Lexicon), a name that, together with the friendly merry atmosphere inside, is in striking contrast to what the Christians experience from their Muslim neighbourhood. The centre also seems to be able, to a certain degree at least, to protect itself: like a fortress, it is surrounded by thick walls, has a massive metal door with a small peephole, and a guard (cf. gated communities, below). 
forced innocent Muslims to adopt Christianity (conversions). The father keeps calm, but also absolutely unyielding, eager not to let the other achieve discursive hegemony. He does not engage with the caller's allegations, steadily insisting that they are completely baseless and unprovable. He does not stop talking in order not to let the caller get a chance to repeat his demands, accusations and threats, addressing the guy like a father who is talking to his adolescent son or one of the son's friends. While the mother, feeling powerless and desperate, is often shown in tears, the father remains determined throughout to prevent the terrorists from getting the upper hand (male vs. female, resistance vs. terror, courage vs. timidity). ${ }^{10}$ In addition, the actions and reactions of the parents' are framed as a challenge to their trust in God (temptation of faith) and as relevant to the project of the nation: asked by Christophe why or for what he was praying, the Father thinks for moment, then replies: "Hmm... - for Egypt! True belief helps!" (patriotism). As for Christophe, the events challenge his previous support of the uprisings: on the one hand, the young man was very positive about them; on the other, he now also sees the consequences (freedom = anarchy: the ambivalent revolution).

Among the structural features of this 62-minute documentary the most noteworthy are probably: (a) the fact that it is filmed free-hand (which underlines the personal engagement of the author while it may also be read as corresponding to the 'shaken' status of the country); and (b) a focus on narrow spaces (e.g. the kitchen in the parents' Cairo flat) and a perspective from within closed rooms (the kitchen, the walled conference centre, the car, etc.), which can be taken as an expression of the restriction of freedom on account of terrorism (inside-private-security/safety $v s$. outside-public-danger).

\section{\#11 'Ākhir 'ayyām al-madīnah}

As already mentioned above, 'Ākhir 'ayyām al-madīnah ("In the last days of the city", 2016) can be classified as a fictionalised autobiographical documentary. The object of the author's documentation however is not only his own, Tāmir al-Sa '̄īd (Tamer el Said)'s alias "Khālid"'s self, but also the character of the Egyptian metropolis in the winter days of the year 2009. With these features the film is not only indicative of the wish, already observed several times so far in the present article (\#6-\#10), to re-assess the past (we may assume: with the idea to understand both the 2011 uprisings and the present, 2016, situation better); it is also a representative of the genre in which the destiny of an autobiographer merges with, and consequently is also narrated as dependent on, that of society at large (individual = collective: pre-Taḥrīr conditions, late Mubārak era). The author's/Khālid's own existential and creativity crisis become a part, and in many aspects also a pars-pro-toto, of the situation in the country. Quite significantly, the film's events all take place in downtown Cairo, i.e., the symbol of the project of a modernisation of Egypt along Western lines. While the author shows his alter ego embedded in family relations (Khālid goes to see his mother, sister, etc.) and as part of a group of colleagues-friends (filmmakers like himself), he and the others are always also moving through the "universe" (AFF: 4) of the city. The many details and snapshot scenes from everyday life that we are presented with are meant

10 From the film's epilogue we learn that the parents are still alive, but also that the death threats have not stopped yet. 
to add up to a quasi-holistic portrayal of this cosmos: the dust (pollution); an old Schindler elevator (remains from the colonial past; modern architecture); a shabby toothless woman in the street (poverty); demonstrating Muslim brothers, armoured police vans, a cordon (religious-political activism, state violence, clashes); people following enthusiastically a soccer match on the TV screens in the windows of big shops (neo-liberal commodities); hospital scenes (health system); a display window with naked mannequins by which Khālid and his guests pass at night, to find the window covered with newspapers the next morning to prevent a view on the uncovered bodies (puritanism); men discussing politics in a street café; the ubiquitous ruin and decay (car wrecks, garbage, the condition of the flats Khâlid is shown by a broker, etc., all this shown unvarnished, often in close-up and slow-motion, in an almost contemplative mood, accompanied by calm music); checkpoints everywhere (precarious security situation); green prayer carpets/mats rolled out in the streets or the corridors of a TV studio (Islamism occupying public spaces); a man beating his wife up (domestic violence); a group of men - thugs or mukhäbarāt?—running after another man and beating him up (state violence); etc. etc. Very often (e.g., when in a taxi or a café), the scenes are accompanied by an underlying audio-track reproducing voices from the radio or TV that fill the space with the authorities' official discourse, creating the type of contrast (official narrative vs. visual evidence) that we are already familiar with from Maḥmūd Sulaymān's "We have never been kids" (\#9) and that we will still encounter on a number of other occasions. - The variety and simultaneous co-existence of phenomena and contrasting/contradicting impressions leaves the filmmaker-protagonist entirely baffled and undecided: What shall he make out of all that? What kind of film should he produce (search for meaning, metafictional reflection)? His colleagues-friends, all from abroad, offer three models, which however all are different from his own case and therefore hardly applicable to his situation: an Iraqi who has left Baghdad and is now living as a refugee in Berlin; another Iraqi who has stayed in the country; and a Beiruti who enjoys the vibrant atmosphere in his hometown and envies Khālid the even more lively world, rich in fascinating contradictions, of the Egyptian megalopolis. In contrast, Khālid, in addition to the loss of home (symbolised in his search for a new flat), is struggling also with losses on a private level (father dead, girlfriend about to emigrate, mother in hospital, the friends leaving...). Facing the disintegration of 'his' Cairo (alienation / ghurbah) ${ }^{11}$ as well as of his dreams and private environment, the only thing he, for the time being, can decide on is to observe, register, document. The result of this process, however, is a portrayal of Cairo not only (though perhaps mainly) as a collapsing universe (cf. the film's quasi-apocalyptic title ${ }^{12}$ ), but also as a "lively organism" and a "site of desires and dreams" (AFF: 4, my translation). With this, the film also shows an affirmation of humanity that is similar to the one we have already come across above in our discussion of some Tunisian shorts (\#1, \#3, \#4). It seems to be a remainder from a macro-structure, to be found as early as in 'Alā' al-'Aswān̄̄'s Yacoubian Building ('Imārat Ya'qūbiyān, 2002), in which individuals struggle to survive in what is perceived as an almighty inhumane 'system', but somehow manage to discover and preserve, or recreate, essentially human(e) traits in life. ${ }^{13}$

11 Cf. Elena CHITI's contribution to the present dossier, esp. section "Space (Homeland as Exile)".

12 Cf. ibid., section "Time (Present as Dystopia)".

13 Cf. GUTH 2009 and 2014.

$J A I S \cdot 16$ (2016): 298-326 


\section{Fiction}

\section{\#12 Hiārr jäff șayfan}

Like in \#11, humanity emerging from encounters of people in the universe of the Egyptian megacity, in spite of its dehumanising atmosphere, is also the topic of the first 'purely fictional' production treated in the present article, the short (30-minute) film Hārr jäff sayfan ("Dry hot summers", 2015) by Sharīf al-Bandarī (Sherif Elbendary). The story is constructed as a crossing of the paths, and an unintended and ephemeral, yet 'necessary' and mutually accepted union, of an old man (Shawqī) and a young woman ( $\left.\mathrm{Du}^{\mathrm{C}} \overline{\mathrm{a}}^{\mathrm{\prime}}\right)$, against all odds: the traffic chaos (congestion, zahmah); the suffocating heat $\left(44^{\circ} \mathrm{C}\right.$ !) and overall dust; the hectic pace and routine of modern life where Shawqī’s busy son, a lawyer, has no time to accompany his frail father to the doctor (private clinic) and $\mathrm{Du}^{\text {c }} \mathrm{a}^{-}$'s fiancé is too busy to accompany her on some urgent pre-wedding errands; the difference in age and sex (He: aged, frail, pitiable, helpless, soon to die from cancer / She: in her mid-twenties, a future bride full of life and energy). Quite significantly, the initial encounter takes place in a taxi, ${ }^{14}$ i.e., a site that forms part of the public space while at the same time creating a certain privacy/intimacy (Shawqī and $\mathrm{Du}^{\text {' }} \overline{\mathrm{a}}^{\mathrm{a}}$ sitting together in the rear seats), and the scene later moves on to places of a similar character: the bride's tailor, her hairdresser, the photographer where the wedding photos will be taken. Unlike all other productions discussed so far, and despite the quasi-asphyxia evoked in the title, this film is full of humour and slapstick-like comedy (one of the many aspects of the emerging genre of $\boldsymbol{a d a b}$ $\boldsymbol{s} \overline{\boldsymbol{a}} \boldsymbol{k h i \boldsymbol { r } ^ { 1 5 }}{ }^{15}$ : the important plastic bag containing Shawq's's medical report (health) that $\mathrm{Du}^{(')} \mathrm{a}$ 's friend erroneously takes with her when the women leave the car and that Shawqi then has to get back; the mobile phone that is in the wrong place at the wrong time (empty battery); many drivers passing by the taxi blowing their horns to congratulate Shawqi and $\mathrm{Du}^{(} \overrightarrow{\mathrm{a}} \mathrm{c}$ whom they take for a newly-wed couple; etc. It is as if the humoristic distance allows for the thinking of what otherwise might be considered unthinkable: the reunification of the fragmented society. Anticipated by the merrily horn-blowing taxi drivers, the 'marriage' of the unlike couple is soon made still more 'imaginable' when the wedding pictures are taken, in absence of the true bridegroom, with Shawqi posing in his place. ${ }^{16}$ Although both

14 Ever since (at the latest) Khālid al-KHAMīsī's semi-fictional collection of an author's conversations with a taxi driver (Tāksī: hawādìt al-mashāwìr, 2006), the Cairo cab has become a site of "urban sociology", "ethnography" and "oral history" where "Herculean tales of the struggle for survival and dignity" are told (from the internet ad for the book's English translation, <https://www.amazon.co.uk/TaxiEnglish-Khaled-Al-Khamissi/dp/999217871X>, as of 05 Nov 2016). - For an early predecessor in modern Arabic fiction cf. Muḥammad TAYMŪR's famous short story F̄̄ 'l-qițār (1917), set in a compartment "On the train"; on it, cf. Werner ENDE's study "Sollen Fellachen lesen lernen?", Die Welt des Islams, 28 (1988): 112-125.

15 Cf. Richard JACQUEMOND's contribution to the present special dossier; see also there for further references on the emerging genre.

16 The photographer says that thanks to Adobe Photoshop, it'll be no problem to replace Shawqī later with the true groom's pictures - another slapstick comedy-like feature. - An aspect that perhaps also is noteworthy in this context is that Shawqī and $\mathrm{Du}^{\prime} \overrightarrow{\mathrm{a}}$, when posing for the pictures, also come closer physically, their bodies touching each other (cf. H. U. GUMBRECHT's definition of arrays as ways in which "artifacts, roles, and activities influence bodies," see my Introduction to the In 2016 project, in the present volume). 
protagonists belong to the (upper?) middle class, their (temporary) union can probably still be interpreted in the more general framework of the obsolescent model of the nation state. While others often consider the fragmentation of society as already too advanced to not treat 'the nation' other than as a phased-out idea of the past, al-Bandarī seems to follow in al-'Aswānī's footsteps, whose Yacoubian Building ended with the wedding, against all odds, of the old and (after a cardiac infarction) rather frail Zakī Beğ with the young Buthaynah - the couple Shawqī-Buthaynah may even be read as direct 'quotation', an intertextual reference to, and/or reverence towards, al-'Aswānī's idea. However, the followership goes only to a certain degree: While al-'Aswān̄ presents the new beginning as a concrete event, al-Bandarī only stages it as a posing 'as if' - a symbol of the possibility, yes, of mutual rapprochement and the emergence of humanity out of chaos and fragmentation; but also a hope that is not devoid of tragedy: the protagonists as well as the viewers know too well that the photo is, after all, nothing but fiction, and the German oncologist who sees Shawqī's X-rays and medical report (foreign experts/specialists) makes clear that the man does not have more than a few days left of his life. So, al-Bandarī's viewers are supposed to be content with less than al-'Aswānī's readers: with the mere fact that something very human(e), a kind of friendship, understanding, sympathy between the protagonists, actually was able to develop in a short time, despite the disparity of their individual characters, needs and life projects.

\section{\#13 Šbābik al-jannah / Les frontières du ciel}

With Šbābik $k^{17}$ al-jannah / Les frontières du ciel ("Borders of heaven”, 2015) we are back to the sadder sides of life. Unlike all other films discussed above, however, this work by the Tunisian director Fāris $\mathrm{Na}^{c} \overline{n a}^{c}$ (Farès Naanaa) does not (on the surface, at least) refer to a current political or social situation. According to some observers, it was exactly this abstinence from references to the troublesome present that contributed to the huge success of the film in its home country: after the 'Arab Spring' and the difficult post-revolutionary years, people seemed to have been grateful for cultural production that did not remind them of their politicised everyday life.

As the Oslo program leaflet has it, the film is "a moving drama about how we react in face of loss and grief. [...] We follow Sārah and Sāmī, an upper middle-class couple who [...] have lost their daughter, Yāsmīn, at the age of five. Instead of portraying this loss with the artistic devices of melodrama, the director has chosen to focus on Sārah's and Sāmī's inner struggle and their feelings of guilt" (AFD: 11, my translation, SG). This makes clear: the film shows an evident interest in psychology and the ways a trauma (in this case: a traumatic loss) is 'processed' and how lives may be rebuilt after a collapse (cf. the many close-ups on the actors' faces with which camera technique makes the viewers observe the protagonists' facial expressions and in this way 'look into their souls'). In the absence of any direct reference to politics it may be too far-fetched to re-introduce a political reading, interpreting the parents' loss of their beloved (five year-old) Yasmīn as the Tunisian people's loss of the dreams and hopes they had put into the (five year-old) 'Jasmine Revolution' and to re-translate the couple's reactions (despair > mutual accusations > severe and sometimes violent marital dispute $>$ temporary separation > slow rapprochement) as a

17 Tunisian Arabic, corresponding to shabābīk in fuṣhā. The meaning here is more like 'fences'. 
representation of the ways Tunisians had dealt with the collapse and the need to rebuild the country and re-organise their lives. Yet, whatever the author's intentions may have been, a structural parallel to political realities can hardly be denied, a fact that, consciously or unconsciously, may have contributed to its success: the many events and discussions, arranged everywhere in the country, on the psychology of trauma and always considered relevant in a societal-political framework, ${ }^{18}$ seem to corroborate such an assumption quite clearly. A reading that does not see the film as exceptional and 'timeless' as many saw it, may also be substantiated by the fact that the film is essentially built on a bipolar structure that is very common in contemporary Arabic fiction: the oscillation of thought between past and present, the individual's mind being constantly occupied with a comparison between both, and an assessment of both in the light of each other (past vs. present). This feature is prominent in many IPAF-listed novels, ${ }^{19}$ and we have also already come across it on several occasions above (\#6-\#11). In Les frontières du ciel, the 'interwovenness' of past and present is marked by a steady alteration of scenes from both time layers. Quite significantly, the past is coloured while the present is in shades of grey. Equally significant is the fact that the woman is quicker than the man in coming to terms with the loss of their child (male vs. female). For Sāmī, the crisis seems to be over when Sāmī no longer has visions of Yāsmīn sitting in the rear of his car. This is the case only after he has paid a visit to the dying father (whom he had hardly known but who had wished to see him and with whom he can tacitly reconcile before his, the father's, death) and attended his funeral. In a nonpolitical reading, the father is just the father and does not have any additional 'meaning'. But what if we also try a political reading? Who would be the dying father then?

\section{\#14 'Alà hallat 'aynī/À peine j'ouvre les yeux}

With 'Alà hallat 'aynī / À peine j'ouvre les yeux (“As I open my eyes", 2015) we are back again to the more 'typical' productions, that is, those which have clearer, if not direct references to the political. The 102-minute film by Laylà Bū Zayd (Leyla Bouzid) is of the type, encountered already several times above (\#7-\#9, \#11), that aims to (document and) explain recent/contemporary history; in its focus on the summer preceding the winter 2010/11 uprisings it is closest to 'Ākhir 'ayyām al-madinah (\#11), which also portrays the pre'Arab Spring' atmosphere as characterised by fear and mistrust, as somehow pending, as if arrived at a dead end (cf. \#11's apocalyptic title), and like the latter (and others) it features as its protagonist an artist (cf. \#5-\#7; cf. also the importance of dancing in \#4). Although 18 year-old Farah's medical school application has just been accepted, her "passion is for music, and her underground band [cf. the political rock bands portrayed in \#7] is just beginning to get noticed. Their music blends rock with daring lyrics that have the raw poetry of spoken word" 20 (challenging/breaking taboos, poetry, originality/authenticity,

18 Cf., in this context, for instance the "colloque du Comité Freud [!]", held 23-24 April 2016 at the Institut français de Tunisie on Les 'printemps arabes' entre effacement et inscription, with the aim of discussing "Regards croisés franco-tunisiens entre psychanalystes [!], artistes et chercheurs en sciences sociales" (<https://www.institutfrancais-tunisie.com/?q=node/11579>, last accessed 16 Dec 2016).

19 See above, fn. 2.

$20<$ https://www.trigon-film.org/en/movies/A_peine_les_yeux>. 
'ämmiyyah). In the director's own words, the young generation's (shabāb)'s desire “to live a life to the full" is opposed here to "family pressure and an omnipresent police state" ${ }^{, 21}$ (Farah's anti-authoritarian revolt is against both). ${ }^{22}$ With these features, 'Alà hallat 'aynī, like many other productions from the same period, is eager to stage a clash between the individual's basically human impulses, wishes, desires, passions, etc., and a whole system that prevents the unfolding of humanity (cf. particularly \#11, above, which also is eager to cover a large variety of scenes from everyday life, breadth equalling the 'almightiness' of the system). A recurring motif in this context is also the fact that in order for the shabāb to live this human life, they have to do it in secret (double life, open vs. secret). The secret, however, cannot be concealed from the System's spies, and both the members of her group and Farah herself have to endure detention and torture. The oppression they experience is essentially the same as the one their parents had been exposed to in their youth or are still undergoing (continuity, stagnation) - "the father works and lives in another city because he refuses to join the president's party" (silent resistance), and the reason for the mother's timidity is that she has been a rebel herself in the past and only knows all too well what the consequences can be (AFD: 9). - The film demonstrates how effective the System's brutal and inhuman techniques of silencing were at the time: when Farah eventually is released she returns broken, unable to speak anymore. But the narrative also ends on cautiously optimistic note (hope, confidence): The mother succeeds in making her daughter recover and begin to express herself again - through singing (!) and, even more significantly, on the text of the rebellious song she used to sing in the bars, the song "Blādī" that comes with harsh criticism of the political and social conditions prevailing in the country (framework: the nation). The last words of the film are the mother's encouraging Kammil! kammil! '23 'Go on, continue, complete!'

\section{\#15 Ma révolution}

Ramzī Bin Sulaymān (Ramzi Ben Sliman)'s Ma révolution ("My revolution”, 2015) starts out in Paris in a Tunisian expat/immigrant milieu. The 'Arab Spring' is celebrated on the streets, as it is also received with great enthusiasm in 15 year-old Marwān's family. The parents follow the reports on the radio and TV with excitement, and the grandfather feels reminded of his own 'revolutionary' youth. But Marwān, who has never seen Tunisia himself and to whom, as a teenager, politics doesn't say much, is busy with other things: how to be accepted among his peers and, still more important, how to win his pretty classmate Sygrid's heart? In this moment, the 'Arab Spring' comes to his aid: One evening he swans around in the streets and joins, just for fun, a group of dancing demonstrators; the next morning, a picture showing him under a poster with revolutionary slogans has made it onto the title page of a magazine, and Marwān suddenly, and completely unintentionally, is a

21 Quoted in: <http://www.venice-days.com/FILM.asp?id=9\&id_dettaglio=552\&lang=eng>.

22 On the situation of Egyptian youth, comparable to that of their Tunisian 'colleagues', and their confrontation with the authorities, cf. Albrecht HOFHEINZ's contribution to the present dossier. - For the "young generation", or "generation of the youth" (jïl al-shabāb), in general, cf. Jacquemond's brilliant article, JACQUEMOND 2015.

23 Unlike in fuṣhà and many dialects where an imperative directed at a woman has to be marked feminine $(-\vec{\imath})$, in Tunisian Arabic it is not kammilī but kammil (like masc.). 
hero. This wins him indeed Sygrid's affections; but in order not to lose her, but rather pass as a truly revolutionary youth, he has to live up to what the people in his surroundings, and particularly Sygrid, now believe him to be and expect of him as the icon of anti-dictatorial protest. Consequently, Marwān starts to learn more about Tunisia, the Ben Ali regime, and the 'Jasmine Revolution', and eventually even follows his parents (back to the roots, identity) who decide to go there for some time in order to live the historic moment and contribute to the reconstruction of the country they had left many years ago. - From this summary it is clear that we are dealing with a film that, like many others, retells recent history and which does so in the modus of a story of coming-of-age/maturation and individual appropriation of the revolution ("my" revolution!). ${ }^{24}$ With this, it bears some similarity to a Bildungsroman, a trait that is not uncommon to find in contemporary Arabic fiction ${ }^{25}$ and that is, perhaps, to be interpreted as an expression of the wish, on the side of the author, to provide the viewers with an exemplary story of an average apolitical cocitizen who succeeded in appreciating the revolution and eventually making it his/her own and who therefore can serve as a model to identify with and to be emulated. ${ }^{26}$ On the side of the viewers, we may assume a wish to find exactly such a pliable personality depicted as an amiable model - it is certainly not without significance that the protagonist is a young, naïve galoot whom we laugh about in the beginning, but who nevertheless always has our sympathy and who later in the film even gains our respect. (That he deserves so is expressed with the help of a happy ending: Although Sygrid is very angry with Marwān because he had left for Tunis without telling her, she is soon ready to forgive him and take him back.)

\section{\#16 Insoumise / al-Mutamarridah}

At the centre of Insoumise / al-Mutamarridah ("Rebellious girl", 2015) by Jawād Ghālib (Jawad Rhalib) we have again, as in 'Alà hallat 'ayn̄̄ / À peine j'ouvre les yeux (\#14), a rebellious young woman (shabäb). Not finding a job at home in the field of her specialisation, internet technology (academic unemployment), modern self-confident Laylà leaves Morocco with the aim to earn some money as a seasonal worker on a farm in Belgium (emigration, migrant labour ${ }^{27}$ ). It does not take long, however, until she becomes aware that she and her likes are being systematically exploited by the employing farmer: hard work, low wages, primitive housing conditions, no rights, almost like in prison. When asking the farmer to stick to the laws and pay the workers for many hours of overtime proves to be of no avail, and after some other incidents, Laylà does some research on her laptop (internet as source of know-how) and eventually decides to report the case to the authorities (whistle-blowing). The situation escalates when the business inspectorate carries out a control and the angry farmer, forced to pay the bill, wants to take revenge on the

24 The process of appropriation is completed only in Tunisia and, significantly, in a scene in a disco (music, hip-hop, dancing): It is here that Marwān merges with the local, revolutionary community/society and in this way becomes a 'real' revolutionary.

25 A prominent example is Yūsuf ZAYDĀN's IPAF winning 'Azāzinl (on which cf. GUTH 2016).

26 For the heroisation of the average citizen in the Egyptian context, cf. section "Everyday Life (Ordinary Citizen as Hero)" in Elena CHITI's contribution to the present dossier.

27 For emigration in Egyptian films, cf. Delphine PAGÈs-El KAROUI's contribution to the present dossier. 
'traitor' by punishing the whole group. What follows is a restaging, en miniature, of the 'Arab Spring': When the injustice suffered from the 'regime' (here: the unjust 'despotic' farmer=ruler) reaches the limit of the bearable, the group revolts against 'the system'. ${ }^{28}$ Dismissed from her job, Laylà, in cooperation with a well-informed local NGO, organises (non-violent) resistance, occupying, fully legally, a public space that is of crucial importance for the farmer (cf. the occupation of Taḥrīr Square). Civil disobedience eventually pays off: the protesters get support from the ministry, and all their demands are fulfilled. - How to interpret this story? I am inclined to read it less as the type of remembering/processing history and studying the recent past in search of explanations for what happened, a type of which we've already seen several examples above (cf. esp. \#7, 9, 11, $14,15)$; rather, I would suggest a reading as the director's attempt to present the rebellion of the Arab youth as something that is of a wider relevance: it's not only the Arab countries but also the West where injustice is found and change is necessary (and morally absolutely justified). As such, the 'Arab Spring' can even serve as an 'export model'! A feature that seems to corroborate such a reading is the story of the Thibaut (a Belgian, i.e., a Westerner) that runs parallel to the other events: Working as a foreman on the farm he forms part of the oppressive system in the beginning; later, he falls in love with Laylà and eventually, after some inner quarrels (Bildungsroman, cf. \#15), even changes sides - the young Arab woman has become a role model for a Westerner to emulate!

\section{\#17 Yā țayr aț-tāàir}

With its happy ending, Yā tayr at-țāyir ("A song for Nour / The idol”, 2015) by Hānī Abū Ascad (Hany Abu Assad) shares with the preceding story (and some others in this survey, cf. \#1, 12-15, 22) a positive, hope-inspiring mood- "a feel-good film", as it is labelled in a standard announcement. ${ }^{29}$ It tells the-real-story of the talented young Palestinian singer Muhammad 'Asāf from Gaza who, with the help of the popular casting show Arab Idol, made it into the charts, won the 2013 contest and thus became a living legend. - The production displays several features that an attentive reader of the preceding descriptions will immediately recognise as something familiar:

- it is all about singing (music, as related to feeling/emotion and authenticity/selffinding/identity, cf. \#4, \#5, \#7, \#14, \#22);

- 23 years old, the hero is a typical young man (shabāab, cf. \#4, \#5, \#7, \#9, \#11, \#\#1416, \#\#20-22);

28 For the 'Arab Spring' as an export model, cf. the volume co-edited by OuALDI et al. 2014. Thank you, Elena, for drawing my attention to this collection and remarking that the tendency to draw a parallel between Arab countries and Europe with regard to economic crisis and social unrest was probably even stronger in literature/fiction. Cf., e.g., Mathias ÉNARD's Rue des voleurs (2012): “This novel, written in 2011, is set between Morocco and Europe, especially Barcelona, where the Spanish economic and social crisis and the 'indignados' are seen in parallel with the crisis that hits Morocco. The hero is Lakhdar, a Moroccan young man in his twenties, trapped in his country and, then, in a hopeless migration. The Arab Springs are a far echo from abroad, both for Morocco and for Spain, where the situation is not better than in the Arab world" (Elena CHITI, e-mail of 12 Dec 2016).

29 <http://www.filmfrasor.no/arabiske-filmdager/afd-filmbase/2016/the-idol>, AFD2016_program: 11. 
- growing up as a Palestinian child ${ }^{30}$ in poverty in the 'hermetically sealed' Gaza strip (comparable to slums / the 'ashw $\overline{\boldsymbol{a}}$ ' $\boldsymbol{i} y \boldsymbol{y} \overline{\boldsymbol{a}} \boldsymbol{t}$ in other countries), he is also a representative of those protagonists who start out from an underprivileged and/or marginalised position and therefore can easily serve for the broad masses as a model to identify with (for children, cf. \#9; poverty: \#1, \#2, \#3, \#8, \#9, \#11; 'ashwā'iyyāt: \#1, $\# 8$, \#9, \#18, \#19; blind: \#1, \#22; weak woman: \#3, \#5, \#9, \#14, \#16, \#18, \#19, \#23), a fact that makes his success all the more miraculous (contrast) ${ }^{31}$

- the hero demonstrates an admirable endurance ${ }^{32}$ and courage, which, combined with his resourcefulness ${ }^{33}$ (cf. \#1, \#3, \#19, \#27) enable him to take the challenge and defy all odds (cf. \#1, \#3, \#4, \#12,\#16,\#22).

In Muhammad's childhood, these odds consist mainly in the family's poverty. When he tries to get out of prison-like Gaza to Cairo, however, there is also the political reality of almost unsurmountable borders, the difficulty of obtaining a passport, etc. An obstacle is also the purist attitude, opposed to 'wordly' singing, of Ḥamās officials (religiosity vs. humanity).

The emotionalism of the film, generated already through the miraculous 'rags-toriches' plot, is further enhanced by the pity the viewer is made to feel with the innocent children who, in the first part of the film, try their best to establish a band. The film becomes particularly moving when Muhammad's sister Nūr who from early childhood has to do regular hemodialysis (health), eventually dies (her life could probably have been saved, had it not been for the political circumstances and the family's poverty). It was she who 'infected/infused' the group with her idealism and strong will and provided them with the belief in the possibility of realising their dream against all odds ("In Gaza? Now? You're crazy!"), and it was she who told Muhammad that he was able to succeed, an idea that later on is also repeated by a grown-up patron: "Don't let anyone tell you that your dreams won't come true." ${ }^{34}$ When he finally decides to participate in the song contest and "get out

30 The first part of the film shows Muhammad as a child.

31 The difference between the world Muhammad comes from and the glamourous world he meets in Cairo when he participates in the Arab Idol contest is enormous. A similarly striking contrast is highlighted particularly in Nawwārah (see \#19, below) where the heroine commutes between the 'ash$w \bar{a}$ iyyah she lives in and the gated community where she works. Social inequality is however also mentioned elsewhere, e.g., in the documentary about Egypt's Modern Pharaohs (\#8). - For other types of contrast (as a structural device used to alert the viewer to relations of dramatic disproportion, disparity, discrepancy, inadequacy, inequality, etc.), cf. \#1, \#22 (blindness/powerlessness/ill-equippedness vs. actual challenge); \#9, \#11, \#19 (official discourse vs. reality); \#10 (love/peacefulness vs. death threats, see fn. 9); \#18 (inside vs. outside).

32 The hero does not give up his childhood dream although in the meanwhile he has to subsist by something as unrelated to his talents as driving a taxi.

33 Without any means, Muhammad and his friends are forced from early childhood to use all resources, so also when it comes to provide their band with musical instruments. Although the money they are able to collect, "wouldn't buy you a string in a flea market" (as one of the persons they approach has it), they eventually get some instruments, etc.

34 English as in the subtitles. Literally, the speaker says: “... that your dreams don’t matter/aren’t important" ('inn i 'ahlāmak mish muhimmah). 
of this place before it finishes me" (emigration, flight), he does so also in the spirit of confidence and self-confidence that he had learned from Nūr. ${ }^{35}$

It goes without saying that all these notions, as well as the high degree of emotionalism, belong to the larger thematic complex of hope (vs. despair, realism, sobriety, etc.) that we have already come across on several occasions (\#4, 6-7, 9, 11-16) and will meet again quite often also in the following. It seems, however, that the most recent productions are more reluctant to tell stories that give reason for optimism. If this is true, then the screening, in 2016, of earlier productions like Yā tayr aț-țayyir would have to be read as an effort to uphold the spirit of hope against an overall movement towards more sceptical or pessimistic attitudes. An example of the latter is

\section{\#18 Ishtibāk}

Ishtibāk ("Clash", 2016) by Muhammad Diyāb (Mohamed Diab). It is not completely devoid of hope, but it is definitely no longer the idealistic hope of Yā tayr at-tâyir that speaks out of this film. In the world that it takes us back to, the Cairo of summer 2013, shortly after the removal of Egyptian president Muhammad Mursī, a world full of violence, social fragmentation and religious-political confrontation (cf. the title, "Clash"), incidents that could give reason to hope are much rarer, more difficult to detect, and perhaps also only ephemeral - although there are no explicit statements about how the viewer should imagine the future: the open ending seems to point in the direction of a renewal of violence and the destruction of the germs of hope that may have started to show first sprouts in the course of the events. Significantly, the space in which the 'clash(es)', announced in the title, take place, is the prison cell-like interior of a police van. ${ }^{36}$ During demonstrations outside (reminding of the disastrous Rabaa [Rābi'a al-'Adawiyya] massacre of August 2013), the van steadily fills up with all kinds of people, representing a cross section of Egyptian society (panoramic/holistic approach, cf. esp. \#7, \#11, \#12, \#19). No question, the van is intended as a symbol of that time's Egypt (the nation): ${ }^{37}$ full to the brim (zahmah, cf. \#\#9-12, $\# 17, \# 19)$, the atmosphere inside relentlessly heating up, with people almost suffocating (asphyxia, cf. \#12), many in need of medical care (health, cf. \#1, \#9, \#\#11-12, \#17, \#19), etc. The film lets the quarrelling of the adverse parties (mostly adherents of the Muslim Brotherhood on the one hand, and secularists/supporters of the army on the other) who have been fighting each other outside, continue also inside the van for some time. But being squeezed into a 'black box' and having to endure the situation without any clue of what is going to happen next (uncertainty), also means sharing a common destiny and having to collaborate in order to survive into an unknown future. Thus, the film also tells the story of a chance, and concrete opportunity-here they are, the germs of hope mentioned above - to overcome mutual mistrust and suspicion ${ }^{38}$ and find a way back to national solidarity 'thanks' to the necessity to fulfill a number of basic human needs (New

35 This is the reason why the film's German title is "Ein Lied für Nour" (a song for Nour).

36 With this feature, the film can be seen as joining in the well-known tradition of 'adab al-sujūn 'prison fiction'. For some early examples of the genre, cf. ALLEN 1995: 109 (with further references); cf. also ASHOUR 2015/16 (written 2008).

37 For other spaces symbolising the nation, cf. GUTH 2011.

38 Who is a Muslim Brother [MB]? Who a journalist? Who a snitch or the agent of some foreign power? 
Humanism, cf. \#1, \#4, \#\#9-12, \#\#16-17, \#\#19-20): to get one's share of fresh air and water, but also the possibility to urinate (a problem particularly for the women - the film shows that it is easier for men to preserve their dignity). ${ }^{39}$ But also discussions about soccer create a certain sense of community; two people even get closer after having found out that they both love dogs; a (presumably Muslim) nurse covers the cross (religious symbols) on the arms of an injured Copt (cf. \#10) to save him from the trouble he might get into if his Christian identity was detected; in order to help the same nurse dress the wound of another prisoner, a young Muslim Sister, until then a strict defender of a dogmatic interpretation of Islam, lends the nurse the safety pins of her hijab, in this way unveiling herself (sacrificing an important symbol of her dignity for the higher cause of helping a fellow human being); this brings out fine long hair the beauty of which completely dazzles a (non-MB) boy of her age; when one of the prisoners, a kind of fat figure of fun (humour, cf. esp. \#12, but also \#1, \#3, \#7, \#15), eventually starts singing and drumming (music, cf. \#\#4-5, \#7, \#14, $\# 17, \# 22$ ) on the salad strainer he had worn as a helmet, everybody even starts laughing, many falling in a mode of remembering, by association, beautiful moments in the past. However, when the 're-humanisation' of this sample group has just started to bear fruit and a new type of community is beginning to take shape, somebody, in the turmoil outside, manages to hijack the van and drive it to some no-man's land. Before the door can be opened the hijacker has to flee again from the police who have tracked the missing car. Trying to escape, the car gets stuck in a demonstration-we don't know whether pro- or anti-MB - seething with rage. The infuriated mob turns the van over, and the door bursts open. The last scene shows a group of protestors dragging some prisoners outside, where, as the viewer can assume, some lynching will take place: we are back to the blind violence with which the film started. ${ }^{40}$ The camera fades out, leaving behind a scene of nightly chaos, with the beams of green laser pointers criss-crossing the darkness, accompanied by melancholic tones from a $n \bar{a} y$. - Seen as a whole, the film should probably be interpreted as another example of a critical assessment of the recent past with the aim of learning a lesson for the present and future: The chance to find a way back to a form of human togetherness is always there, it was even there in summer 2013; it fell prey to blind violence then, so let's stop this, and find a way back to the values of humanity.

39 In this context, the MB are portrayed as being experienced in organising themselves, but also as rather egoistic and mechanically bureaucratic: as soon as a group enters the van, they find a group leader, who immediately starts to divide the prisoners into $\mathrm{MB}$ and non-MB, and the MB into those who are registered members and those who aren't, making clear that only the registered MB will get group support. The viewer must conclude: for the MB, not the human being as such is what counts. - Another egoist is a young DJ: hiding his mobile from the rest of the group, he simply listens to some hip-hop music, in this way using up the battery (empty battery, cf. \#12) of the phone that could be used to get contact to the outside world.

40 In the beginning, acts of violence not only committed by the protesters in the street but also by the police: When they get hold of a sniper they beat him up and let him die from the kicks (in revenge for the colleague he had shot), and an ambulance (which perhaps could have helped) drives away. When the MB girl in the van needs a toilet and one of the policemen wants to help, he is sent to jail by his superior. 


\section{\#19 Nawwārah}

Hālah Khalīl (Hala Khalil)'s drama Nawwārah ("Nawara", 2015), too, takes the viewer back to the recent past - the days of the January 2011 uprisings - and in this way, like many others, makes an attempt to reassess this crucial period (cf. \#\#7-11, \#14-15). Unlike the previous and other films that have a similar objective, however, there are no sparks of hope left here. The film closes on highly pessimistic prospects: ${ }^{41}$ an innocent, brave, hardworking, poor woman who has sacrificed herself for the cause of a super-rich family, is accused of being a thief and will probably be punished as a criminal-a dramatic ending that serves the task of underlining the striking injustice and social inequality prevailing in the country. As such, the ending is in line with the main structural principle the film operates with: the highlighting of contrasts (presumably with the aim of emotional mobilisation), which in this case means: the tremendous gap between the rich and the poor in Egypt. The contrast is also carved out in spatial terms: the heroine Nawwārah commutes regularly between her home in one of the 'ash $\boldsymbol{w} \overline{\boldsymbol{a}} \boldsymbol{i} \boldsymbol{i} y \boldsymbol{y} \overline{\boldsymbol{a}} \boldsymbol{t}$ and the place where she works as a housemaid, a villa in one of the gated communities of New Cairo (al-Qāhirah al-Jadīdah) ${ }^{42}$ the distance between the two spaces (and classes) is underlined also by following the protagonist on her daily way to work, a trip that takes hours and involves changing the means of transport several times: first a tuk-tuk, then a public bus, then a minni-bās, then another bus (inside the compound). Contrasting the two worlds of poverty and luxury in spatial terms is however only one aspect of a technique of systematic alteration put into operation throughout (evidently intended to cover the manifold aspects of one system, holistic approach). For instance,

- after showing the heroine toiling to carry water to her house in large cans from a central tap in the quarter, there is a shift of scenery to the rich villa where the bikiniwearing daughter slips into a private swimming pool full of precious water that is 'just there', serving no other purpose than to grant the rich the opportunity of a quick refreshment in the heat;

- while Nawwārah's family has to work hard to be able to buy some meat (affordable food), the rich family's dog (named "Butch") gets kilos of the best meat every day;

- while the heroine and her husband have not yet 'consummated their marriage' because they still do not have a flat of their own (lack of affordable housing) due to the husband's unemployment (which in turn seems to be due to, among other things, his low social status as a Nubian [the underprivileged, marginalised]), the villa has plenty of rooms, a garden, etc., and the family members don't even have to work;

- the amount of money Nawwārah's father-in-law, suffering from cancer, would need to have a necessary operation done on him and get adequate medical treatment in a hospital has always been lying 'just there', in a drawer of a desk in the villa;

41 On the lack of perspectives, particularly for the youth, cf. Albrecht HOFHEINZ's contribution to the present dossier special, esp. section "Generation Stuck".

42 "one of the new cities which have been built in and around Cairo to alleviate the congestion in downtown Cairo", "established in the year 2000 by presidential decree" - <https://en.wikipedia.org/wiki/ New_Cairo>.

$J A I S \cdot 16$ (2016): 298-326 
- while the villa's toilets are spacious, modern and clean, those at Nawwārah's home and in the hospital are in a deplorable condition (hygiene);

- concerns like that of Nawwārah's grandmother about whether she one day will be able to afford a suitable shroud to be buried in dignity are completely alien to the rich family; etc.

Other occasions where the director applies a contrasting technique include dichotomies like

- official discourse vs. lived reality: Deplorable conditions are often depicted with a voice from the radio, already familiar to us from other films (cf. \#1, \#9, \#\#11-12), in the background, spreading the latest news; the voice is present, for instance, when Nawwārah is cleaning a toilet, or when she is on a bus, or when another housemaid one day brings along her daughter whom she has taken out of school so that she can help earn the family's living (education falling prey to economic needs);

- false appearance $v$ s. true being: The 'almighty' nurse in the hospital where the father-in-law is waiting to be treated bears the promising name of Mu'mina ("Believer"), but instead of doing her job and caring about the patients she is always on the phone discussing non-related trivialities with a friend or relative (cf. also false Islam);

Another example of the dichotomy between official discourse and lived reality are the promises the SCAF interim 'government' spreads in the media, saying that the assets of the presidential family will probably be redistributed to the people so that each citizen could reckon with c. $£ E 200,000$ in the not too distant future, a promise that injects new hope in Nawwārah and lets her remain confident that after the Revolution things will take a turn for the better.

The two-hour film is very rich in details and all kinds of allusions that cannot be treated in the present survey due to limitations of space, although they are recurrent in other productions as well: cf., e.g., the notorious traffic chaos / zahmah; the constant time pressure / hectic rush resulting from the need to commute between home and two or three jobs and leading to an exhaustion of the body; the resoluteness and courage needed to meet the challenges of everyday life, a feature often shown especially in young women; the lack of security; the frequent protest marches in the streets demanding bread, freedom and social justice, etc. Before going over to the next film, however, I would like to draw attention to two more features that seem to me particularly noteworthy:

- Nawwārah's husband 'Alī suffers from a feeling of emasculation ${ }^{43}$ because he is unable to provide housing and a living for his wife and help his sick father. Although, in its essence, nothing but a variant of the feeling of powerlessness/impotence that we have met on several occasions already above $(\# 1-2,10)$, the direct topicalisation, in this film, of a well-known phenomenon seems to me rather unusual. It still seems to be a taboo, and perhaps needed a female director like Hālah Khalīl to address it.

43 We hope to read more on this topic in general in a doctoral thesis on "Passionate Publics: Emotions \& Events through Media in the \#Jan25 Revolution", currently prepared by Yasmeen MEKAWY, PhD student in Political Science at the University of Chicago. 
- No doubt, the film bears many traits that are typical of the melodramatic genre (particularly its closure with Nawwārah's arrest and her being driven away in a police van, behind bars, under the false accusation of theft). And it seems also clear that the heroine's modesty, unshakeable honesty (steadfastness), loyalty towards her employers without any feeling of envy, as well as her sense of duty, upheld even under the most difficult circumstances, are a slightly idealistic construction (necessary perhaps in order to let her, the icon of the innocent average citizen, appear as upright and immaculate as possible). The film does however not forgo staging temptation, moments when the poor cannot resist taking something from the rich. This role, however, is assigned to the heroine's husband, 'Alī. While the rich employers' affluence is clearly shown as immoral, and the theft of a precious clock that 'Ali commits when the house is empty, is thus made understandable, he nevertheless feels remorse and brings the clock back, so that the honour of the average citizen is restituted and the rich remain the only real object of criticism.

\section{\#20 'Ākhir wähid fīnā}

'Ākhir wāhid finnā ("The last of us", 2016) by 'Alā' al-Dīn Salīm (Ala Eddine Slim) seems, at first sight, to be completely different from all the productions we have described so far. This impression owes itself, in the first place, to the fact that the film does without any dialogue at all; that socio-political topics are absent; that the protagonist as well as the regions he crosses and the places he passes by all remain nameless; and that the main part takes place in a kind of primeval forest, with the protagonist and his senior 'mentor' living almost like Stone Age men-features that lend the film the character of "philosophical science-fiction" (as the AFD2016 leaflet has it). ${ }^{44}$ On closer analysis, however, we find that, despite its different appearance on the surface and high degree of symbolic-mythical abstraction, ${ }^{45}$ the film nevertheless shares a number of traits with other productions of the present survey. Among these is the fact that we are dealing with a kind of Bildungsro$\boldsymbol{m a n}^{46}$ (cf. \#15-16, to a certain extent also \#17-18; see also \#21-22, below). It tells the story of a young (shabāb) refugee $^{47}$ (from some North African country, as it seems) who leaves everything behind, makes his way to the coast, captures a boat and, in spite of being shipwrecked (on the Mediterranean?), manages to reach a safe (European?) shore and, recovered, starts his way into the jungle-forest mentioned above (journey ${ }^{48}$ ). It doesn't

$44 \mathrm{Cf}$. also the interruption of the narrative, in the middle of the movie, by a black screen showing only some poetry verses and an art design composed of smaller and larger circles, on the bottom right of the screen.

45 In our sample of 23 movies, there is only Qindīl al-baḥr (\#23) using non-realistic elements from the mythical heritage.

46 The AFF2016 leaflet calls it "eine unglaubliche Reise zum eigenen Ich" (an unbelievable journey to the self).

47 Perhaps in search of a living, like the migrant worker of \#16. - Cf. also note 27, above.

48 The organisation of a Bildungsroman as a journey is a typical feature of the genre since its very emergence. Not surprisingly, we find a similar structure also in other movies from our survey: e.g., there is a lot of walking/driving through the streets in 'Ākhir 'ayyām al-madīnah (\#11) where Khālid is searching for 'the meaning of all this'; in Ma révolution (\#15), the young Marwān has to travel to Tunisia in order to really come of age; as we shall see soon, the protagonist Hādī in Nhibbik, Hādī (\#21) lives his true 
take long until he falls into a deep pit trap and is seriously injured, but then also rescued and medically treated by an old hermit. The latter soon becomes his teacher and guide in the New World. ${ }^{49}$ However, when he just has learned enough-about the New World and himself ${ }^{50}$ - to be able to survive on his own the 'mentor' one day is injured (by a wolf?) and dies. Now our young hero 'takes over' from the old man, and the final scene shows him, completely naked, in front of a beautiful little lake under a waterfall, ready to start into a new life, relying only on himself. - While the quasi-apocalyptic title "The last of us" is reminding of Tāmir al-Sa ${ }^{c} \overline{1} d$ 's "In the last days of the city" (\#11) that evokes similar visions of an end time in the spectator, the meaning of the final, cautiously hope-inspiring scene rather seems to be similar to the note on which a film like "As I open my eyes" (\#14) leaves us: the hero/ine has gone through great hardship, yes, and given these difficulties, the future will certainly not be easy; however, what is more important is that the hero/ine actually has survived all this, learned a lesson, and that his/her will to life is unbroken-the AFF leaflet speaks of a "rebirth". ${ }^{51}$ At the same time, this rebirth also means a victory of the human over what perhaps can be described as 'posthuman': 52 the movie opens with showing the hero in a deserted wilderness, at night in a cold windy wasteland; then, when the refugee comes closer to civilisation, there are mainly motorways; then he is alone on the sea, exposed to the freaks of nature (powerlessness), which he also is after arrival on the safe shore and when he starts to move further uphill through the jungle; in this seemingly depopulated world, the protagonist indeed looks as if he was "the last of us", the last surviving member of the human species, constantly threatened by extinction (the film underlines the danger, fear, difficulty of survival). It is significant, however, that his way almost always leads uphill (indicating ascent to higher levels) and that, after the death of the mentor, he is always accompanied by a brightly shining full moon - as if the spirit of old man was continuing to illuminate his way. (Should we interpret this as the author's vision of how the $s h a b \bar{a} b$ can profit from the experience of the older generation?) Thus, the naked youth of the final scene who is at the beginning of a new life characterised by independence, self-reliance, authenticity, and freedom, but also by the vulnerability of the naked, can always also feel guided and, in a way, protected by the spirit of the Old Man.

\section{\#21 Nhibbik, Hādī/Hédi}

Another Tunisian movie from the current year, Nhibbik, Hādī / Hédi ("I love you, Hedi", 2016) by Muhammad Bin 'Ațiyyah (Mohamed Ben Attia), re-enacts a plot that is familiar to any historian of modern Arabic fiction ever since the so-called 'first Egyptian novel', ${ }^{3}$

self in another place; and the young blind protagonist in $\operatorname{Rabi}^{c} /$ Tramontane (\#22) finds out who he really is via a journey through his country, Lebanon.

49 After the hero's compass had run riot in the New World, the hermit provided him with a new orientation.

50 Cf. previous note.

51 Cf. the discussions about a 'new Nahdah' in the Arab World.

52 Cf. the title of the $12^{\text {th }}$ meeting of the European Association for Modern Arabic Literature in Oslo earlier this year (May/June 2016): "Upholding Humanity in a Post-Human World? Arabic Literature after the "Arab Spring"', see $<$ https://euramal12th.wordpress.com/ $>$.

53 On this label cf. Colla 2009. 
Muhammad Husayn Haykal's Zaynab of 1913: a young male protagonist ${ }^{54}$ torn between two women, one of whom representing Tradition, the other Freedom. While Zaynab belongs to the period of early nation-building, Hédi can without doubt be watched as a document of nation-rebuilding. The two options are still coded very similarly: Tradition is what the older generation/parents want and arranges for the youth; what seems to be a safe and comfortable way to go; but which at the same time is quite boring, limiting the individual's longing for naturalness and authenticity, something that does not correspond to the true self any longer and that therefore also is unwanted, mainly a fulfilment of duty; Freedom, on the other hand, is the more appealing and exciting option, but it is also more risky and adventurous, and therefore more demanding. Judging from his way of thinking and feeling, Bin 'Ațiyyah's Hādī is, like Haykal's Hāmid, essentially a drop-out of society already: he doesn't really care any longer, either about the arrangements and decisions his parents make for him, or about his job: he feels as alienated (ghurbah) from the logics of Tradition (arranged marriages) as from those of the neo-liberal market economy. Buthe is too weak to take a stand; he prefers to lead a double life, torn and undecided between his unauthentic/false and his true identities. He knows and feels what would be the right thing to do, but he doesn't. Thus, in the end, he passes up the chance to begin a new life with beautiful, self-confident, independent Rìm, a dancer and entertainer at a tourist resort (freedom away from home, cf. \#4) whom he had met and fallen in love with far away from his home town and with whom he later on agreed to leave for France (spatial distance, contrast); instead, he decides to stay, so the viewer can assume that he will soon marry, as planned by the parents (and, in particular, by his eager mother), Khadijah, ${ }^{55}$ the girl "they" have selected for him; whom he has met and talked to only a few times before; and whom he has never kissed even once (while he has enjoyed sex with Rīm)...

\section{\#22 Rabĩ / Tramontane}

Treating the Lebanese production $R a b \bar{l}^{c}$ / Tramontane ("Rabih", 2016) by Vatche Boulghourjian after 'Ākhir wāhid fin̄ā (\#20) and Hédi (\#21) will reinforce our impression that the present conditions in the Arab world give room for both, cautious optimism and despair. While Hédi closed on a pessimistic note (perhaps deliberately so, in order to mobilise the spectators, make them revolt against weak acceptance of the 'old way' and, with it, also a certain authoritarianism), $R a b \bar{l}^{c}$ joins 'Ākhir wăhid finā in the confidence that the youth does have the potential to find their true identity and in the future will manage, despite all obstacles and own vulnerability, a life as they themselves. $R a b \bar{l}^{c}$ tells the story of a blind young man (powerlessness, shabāb) with a beautiful voice (singing) who one day discovers that he is not the person he has always believed himself to be (uncertainty, identity). His 'mother' and her brother, "uncle Hishām", had made him believe that he was an orphan who had been handed over to them after the death of his real parents in a village in Southern Lebanon. Rabīi senses that something is wrong here, and sets off (journey) to find out what actually happened (official discourse vs. hidden truth). His investigations into the hidden secret past lead him, like a detective, through his country and eventually

54 Hādī is 25 years old.

55 Cf. also the 'telling' names: Rīm = the 'gazelle' (beauty, freedom, life in nature), Khadījah = traditional Islamic name in reverence for the Prophet's first wife (tradition, Islam, conforming to norms). 
reveal the truth to him: During the Civil War, Hishām, then head of a militia squadron, had raided a village and killed Rabī's parents (war crime, violence); their baby, a little boy, became blind from the heat when the house was burnt down, but was saved from the flames; Hishām then gave him to his sister who had always wanted (but herself been unable) to have a child. But still: although the truth now has been established, it will not be acknowledged by the authorities and $\operatorname{Rabi}^{-1}$ will not get the new birth certificate he needs to issue the passport (bureaucracy) that would allow him to join the choir whose soloist he is (music), and who has been invited to a concert tour through Europe. Stuck between accepting or rejecting Hishām's offer to help, he lets the 'uncle' (who has killed his parents and obscured his crime) use his contacts ("vitamin B") and provide a new certificate- a decision that the viewer may interpret as a first step on the way to reconciliation with the murderers of the past (dealing with trauma). Interestingly, the new certificate only confirms the data of the earlier, forged document so that "Rabī" remains Rabī' and his 'mother' his mother (keep appearances). This allows the young man to 'remain the same' irrespective of his 'rebirth', and the older generation to save face in spite of having committed a crime, which makes it easier for the 'mother'/mother to ask Rabî' to pardon her. The final scene shows Rabīi singing, in a public performance together with the choir, the famous Șabāh Fakhrī song with the telling first line: Ib'at-lī gawāb wi-tammin-nī... "Send me a letter/an answer and assure me that everything is all right..." ${ }^{56}$ While the "mother'/mother is sitting in the first ranks, extremely proud of her 'son'/son, 'uncle' Hishām joins the concert only later (out of bad conscience, but signalling interest/acknowledgment?) and remains in the background.

\section{\#23 Qindīl al-bahr/Kindil}

The last movie to be presented here, Qindīl al-bahr / Kindil ("Kindil / The jellyfish", 2016) by the Algerian director Damien Ounouri, is the only one in this survey to use elements of the fantastic to a larger extent. (The lantern-like full moon following the protagonist in \#20, 'Ākhir wähid finā, is the only comparable element, but it is far from being so central there.) The description of the (rather short: 40-minute) film on the website of the Hamburg Film festival where it was shown in Sept./Oct. starts like this: "Nfissa [Nafîsah] is enjoying an outing to the seaside [sea, freedom, be yourself, feel your body ${ }^{57}$ ] with her family when she is surrounded by a group of men, who harass and abuse the young mother [sexual harassment, helplessness] so much that she ends up drowning. [...] Nfissa's husband calls the police, but her body is never found [bureaucratic routine, powerlessness]. Then, one by one, a mysterious series of deaths begins, and male bathers are the victims. ${ }^{" 58}$ The killer is, of course, Nafisah who in the meantime has mysteriously transformed (metamorphosis / transfiguration) into a Medusa and is now taking ruthless revenge (the scenes showing

56 Text by Husām al-Dīn al-KHAṬ̄̄B, music by Bakrī al-KuRDī.

57 It is noteworthy how close the camera gets to the female body in the scene when Nafisah starts to enjoy swimming in the sea. She still has her clothes on, but in the water the dress hardly conceals the details of her body. In its quasi-nakedness, the scene is therefore comparable to the final scene of 'Ākhir wāhid finā (young man standing naked at a lake, ready to meet the future-vulnerable, but free and he-himself; see above, \#20).

58 <http://www.filmfesthamburg.de/en/programm/Film/27321/kindil> (accessed 16 Nov 2016). 
the attacking fish-woman-monster remind of horror films like Spielberg's Jaws and its white shark). Obviously, the film draws on ancient mythology, in this way neglecting Islamic imagery in favour of the pre-Islamic cultural heritage as a source of inspiration; however, the Greek Medusa's lethal gazes are accompanied by a kind of electric shock in the modern Algerian adaptation. In addition, the AFF leaflet draws our attention to what may be yet another intertextual correspondence: Nafìsah-Qindīl, it says, makes use of the sea in the same way as resistance fighters use the forests for their acts of subversion and revolt (AFF: 9). Apart from highlighting the brutality of sexual harassment, the film is also eager to show what it actually destroys, how terrible it is for those who remain behind, and in this way, contrast it with the love between the married couple, a love that, on Nafìsah's side, is even so strong that she lets her husband lure her from the safe sea into the trap that the police has put up for her. Once she is on the beach the policemen surround and kill her with harpoons - a scene that parallels the initial harassment and in this way points to the similarity between the security forces and the harassers: the same brutality, the same disrespect for the violated female human being.

\section{The films}

\#1 Shüf/Chouf (“Look!”), short film by Imen Dellil; Tunisia 2014, 25 min.

\#2 Condamné à l'espoir (Doomed to hope), short film by Youssef Ben Ammar; Tunisia 2014, 25 min.

\#3 Les commerçantes (“The tradeswomen”), short film by Noussaiba Msallem; Tunisia 2015, 24 $\min$.

\#4 Travesties, short film by Safoin Ben Abdelali; Tunisia 2015, 21 min.

\#5 Un cercle autour d'une danse ("A circle round a dance"), short film by Mouna Louhichi; Tunisia 2015, 18 min.

\#6 Tahar Cheriaa: Taht zilāl al-bāwbāb/ A l'ombre du baobab (“At the baobab's shadow”), documentary by Muhammad Shallūf (Mohamed Challouf); Tunisia 2015, 70 min.

\#7 Yallah! Underground, documentary by Farid Eslam; Egypt, Czechia, Germany, UK, Canada, USA 2015, $85 \mathrm{~min}$.

\#8 Egypt's Modern Pharaohs, documentary trilogy by Jīhān al-Ṭāhirī (Jihan El-Tahri); Egypt, France, USA, Qatar 2015/2016, 3 x 58 min. (Arabic, English voice-over)

\#9 'Abadan lam nakun 'atfālan ("We have never been kids"), documentary by Maḥmūd Sulaymān (Mahmood Soliman); Egypt, U.A.E., Qatar, Lebanon 2016, 99 min.

\#10 al-Salāt wa'l-ma'rakah / La Vallée du Sel ("Prayer and Battle / The Valley of Salt"), documentary by Christophe Majd̄̄ Șābir (Magdy Saber); Egypt, Switzerland 2016, 62 min.

\#11 'Ākhir 'ayyām al-madīnah ("In the last days of the city"), by Tāmir al-Sa'̄îd (Tamer el Said); Egypt, Germany, UK, U.A.E. 2016, 118 min.

\#12 Hārr jāff șayfan ("Dry hot summers"), short film by Sharīf al-Bandarī (Sherif Elbendary); Egypt, Germany 2015, 30 min.

\#13 Šabābik [sic!] al-jannah / Les frontières du ciel ("Borders of Heaven"), by Fāris Na'nāc (Farès Naanaa); Tunisia, U.A.E. 2015, $95 \mathrm{~min}$.

$J A I S \cdot 16$ (2016): 298-326 
\#14 À peine j'ouvre les yeux (“As I Open My Eyes”), by Leyla Bouzid; Tunisia, France, Belgium 2015, $102 \mathrm{~min}$.

\#15 Ma révolution ("My revolution”), by Ramzī Bin Sulaymān (Ramzi Ben Sliman); France, Tunisia 2015, 80 min., (French, Arabic)

\#16 Insoumise / al-Mutamarridah ("Rebellious girl”), by Jawād Ghālib (Jawad Rhalib); Morocco, Belgium 2015, 75 min., (Arabic, French)

\#17 Yā țayr al-țāyir (A Song for Nour), by Hān̄̄ Abū As'ad (Hany Abu Assad); Palestine, Qatar, NL, U.A.E., UK 2015, $100 \mathrm{~min}$.

\#18 Ishtibāk (“Clash”), by Muḥammad Diyāb (Mohamed Diab); Egypt, Germany, France 2016.

\#19 Nawwārah ("Nawara”), by Hālah Khalīl (Hala Khalil); Egypt 2016, 111 min.

\#20 'Ākhir wāhid fiñā ("The last of us"), by 'Alä’ al-Dīn Salīm (Ala Eddine Slim); Tunisia, Qatar, U.A.E., Lebanon 2016, 95 min.

\#21 Nhibbik, Hādī / Hedi ("Hedi”), by Muhammad Bin 'Ațiyyah (Mohamed Ben Attia); Tunisia, Belgium, France 2016, 93 min.

\#22 Rabĩ / Tramontane ("Rabih"), by Vatche Boulghourjian; Libanon 2016, $110 \mathrm{~min}$.

\#23 Qindīl al-bahrr (“Kindil”), short film by Damien Ounouri; Algeria, France 2016, 40 min.

\section{Bibliography}

AFD = Kindt, Kristian Takvam, and Granlund, Gjermund. 2016. Arabiske filmdager / Ayyām al-fïlm al-'arabi, 14.-17. april 2016. Festival program leaflet, accessible also online: <http://www. filmfrasor.no/export/sites/filmfrasor/arabiske-filmdager/presse/ AFD2016-programmagasin-skjerm. pdf $>$. Cf. also website < http://www.filmfrasor.no/ arabiske-filmdager/program/> (last accessed 27 Oct 2016).

AFF = Verein arabischer Studenten und Akademiker Tübingen / Ittihāàd al-țalaba wa'l-'akādīmiyyīn al-'arab Tyūbingen. 2016. Arabisches Filmfestival / Mihrajān al-film al-'arabī, Tübingen, 7.15.10.2016. Festival program leaflet, accessible also online: <http://www.arabisches-filmfestival. de/2016/download/AFF-Programm-2016.pdf $>$. Cf. also website <../2016/filmprogramm.htm> (last accessed 27 Oct 2016).

Allen, Roger. 1995. The Arabic Novel: An Historical and Critical Introduction. $2^{\text {nd }}$ ed., New York: Syracuse UP, 1995.

Ashour, Radwa. 2015/16 [2008]. "Arab Prison Literature”. Ibn Rushd Foundation, Magazine, 18 (Winter 2015/16), <http://www.ibn-rushd.org/typo3/cms/index.php?id=368\&L =1>. Available also as pdf: < ../cms/fileadmin/Ibn_Rushd/magazine/radwaashour.pdf $>$.

Colla, Elliott. 2009. "How Zaynab Became the First Arabic Novel". History Compass, 7, DOI: $<10.1111 / j .1478-0542.2008 .00573 . x>$.

GuTH, Stephan. 2003. Brückenschläge: Eine integrierte 'turkoaraabische' Romangeschichte (Mitte 19. bis Mitte 20. Jahrhundert). Wiesbaden: Reichert. (literaturen im context; 14).

—. 2009. "Post-Postmoderne oder ...? Ein komponentialanalytischer Versuch zu 'Imārat Ya'qūbiyān und Banāt ar-Riyād «. In: XXX. Deutscher Orientalistentag, Freiburg, 24.-28. September 2007: Ausgewählte Vorträge, ed. R. Brunner [et al.], online publication (Dec. 2009), <http://orient.ruf.uni-freiburg.de/dotpub/guth.pdf>. 
— . 2011. "Between 'Awdat al-rūh and 'Imārat Ya'qūbiyān: What has changed in community narratives?" In: From New Values to New Aesthetics: Turning Points in Modern Arabic Literature, ed. S. Guth \& G. Ramsay, vol. II: Postmodernism and Thereafter, Wiesbaden: Harrassowitz, 2011: 95-107.

- . 2014. "The Changing Role of Pleasure, or: Towards a fundamentalist humanism: Some thoughts on the place of pleasure and desire in the system of a new period". In: Desire, Pleasure and the Taboo: New Voices and Freedom of Expression in Modern Arabic Literature, ed. S. Boustani [et al.], Pisa \& Roma: Fabrizio Serra Editore, 2014: 115-141.

- . 2016. "Avatar and 'Azāzīl - Western and Middle Eastern patterns of individual revolt: An essay in the simultaneity of ruptures." In: La littérature à l'heure du Printemps arabe, ed. S. Boustani [et al.], Paris: Éd. Karthala, 2016: 53-86.

— . *2017 [in preparation]. "Arabic Fiction of the last decade: general remarks (based on a diagonal reading of IPAF-listed novels".

JACQUEMOND, Richard. 2015. "Un mai 68 arabe? La révolution égyptienne au prisme du culturel”. REMMM 138 (Dec. 2015): 131-146.

KIRK, Ashley. 2016. "Iraq and Syria: How many foreign fighters are fighting for Isil?" The Telegraph [UK], 24 March 2016, <http://www.telegraph.co.uk/news/2016/03/29/iraq-and-syria-how-manyforeign-fighters-are-fighting-for-isil/>.

Oualdi, M'hamed / Pagès-El Karoui, Delphine / Verdeil, Chantal (eds.). 2014. Les ondes de choc des revolutions arabes. Beyrouth: Presses de l'Ifpo. (Collection Contemporain publications; 36). <DOI: 10.4000/books.ifpo.6686>.

SELIM, Samah. 2004. The Novel and the Rural Imaginary in Egypt, 1880-1985. London: RoutledgeCurzon.

(C) Stephan Guth, Dept. of Cultural Studies and Oriental Languages (IKOS), University of Oslo, Norway

$\checkmark$ stephan.guth@ikos.uio.no 